\title{
Paracetamol (Acetaminophen) Decreases Hydrogen Sulfide Tissue Concentration in Brain but Increases It in the Heart, Liver and Kidney in Mice*
}

\author{
Bogdan WILIŃSKI, Jerzy WILIŃSKI, Eugeniusz SOMOGYI, Marta GÓRALSKA and Joanna \\ PIOTROWSKA
}

Accepted October 05, 2010

\begin{abstract}
WiliŃSKi B., WilińSki J., SOMOgYi E., GÓRALSKA M., PiOTROWSKA J. 2011. Paracetamol (acetaminophen) decreases hydrogen sulfide tissue concentration in brain but increases it in the heart, liver and kidney in mice. Folia biologica (Kraków) 59: 41-44.

The biological action of N-acetyl-p-aminophenol - paracetamol (acetaminophen) has been demonstrated to involve different mechanisms and is still not clear. Hydrogen sulfide $\left(\mathrm{H}_{2} \mathrm{~S}\right)$ has been shown to play an important role in many physiological and pathological processes including nociception. The interaction between acetaminophen and endogenous $\mathrm{H}_{2} \mathrm{~S}$ is unknown. Twenty four female CBA strain mice were administered intraperitoneal injections of N-acetyl-p-aminophenol solution: paracetemol in doses of $30 \mathrm{mg} / \mathrm{kg}$ b.w. per day (group $\mathrm{D} 1, \mathrm{n}=8$ ) or $100 \mathrm{mg} / \mathrm{kg}$ b.w. per day (group D2, $\mathrm{n}=8$ ).. The control group $(\mathrm{n}=8$ ) received physiological saline in portions of the same volume $-0.2 \mathrm{ml}$. The measurements of tissue $\mathrm{H}_{2} \mathrm{~S}$ concentration were performed with the Siegel spectrophotometric modified method. In the brain, the $\mathrm{H}_{2} \mathrm{~S}$ tissue level decreased, but more significantly in the lower drug dose group. Conversely, there was a significant rise in the $\mathrm{H}_{2} \mathrm{~S}$ tissue concentration in D1 and D2 groups in heart and kidney with the increase more pronounced in the group with the lower paracetamol dose. In the liver only the higher acetaminophen dose elicited a change in $\mathrm{H}_{2} \mathrm{~S}$ concentration, increasing after administration of acetaminophen at $100 \mathrm{mg} / \mathrm{kg}$. Our study demonstrates that paracetamol induces $\mathrm{H}_{2} \mathrm{~S}$ tissue concentration changes in different mouse organs.
\end{abstract}

Key words: Paracetamol, acetaminophen, hydrogen sulfide, pain, nociception.

Bogdan WILIŃSKI, Marta GÓRALSKA, Department of Human Developmental Biology, Jagiellonian University Medical College, Kopernika 7, 31-034 Kraków, Poland.

E-mail:bowil@interia.pl

Jerzy WILIŃSKI, I Department of Cardiology and Hypertension, Jagiellonian University

Medical College, Kopernika 17, 31-501 Kraków, Poland.

E-mail:putamen@interia.pl

Eugeniusz SOMOGYI, Joanna PIOTROWSKA, Department of Inorganic and Analytical Chemis-

try, Jagiellonian University Medical College, Medyczna 9, 30-688 Kraków, Poland.

E-mail: jpiotrowl@cm-uj.krakow.pl

$\mathrm{N}$-acetyl-p-aminophenol - paracetamol (acetaminophen) is an example of a paradox in medicine. Despite lacking basic knowledge of the mechanisms of action of paracetamol, its antipyretic and analgetic properties have been successfully used, including pediatrics and over-the-counter sale, for over 50 years (BERTOLINI et al. 2006). Also paradoxically, studies of the recent decade have changed the perception of hydrogen sulfide $\left(\mathrm{H}_{2} \mathrm{~S}\right)$ from a rotten egg odorous poisonous gas to a 'gasotransmitter' and an important co-regulator of nu- merous endogenous processes in mammals (ŁOWICKA \& BEŁTOWSKI 2007). Since paracetamol affects some processes that $\mathrm{H}_{2} \mathrm{~S}$ is recognized to co-modulate, like nociception, the question arises if the biology of acetaminophen involves $\mathrm{H}_{2} \mathrm{~S}$ (LEE et al. 2008). The influence of paracetamol on $\mathrm{H}_{2} \mathrm{~S}$ generation and the role of the gasotransmitter in the biological effects of the drug are unknown. The aim of this study was to assess the impact of acetaminophen on the tissue $\mathrm{H}_{2} \mathrm{~S}$ concentration in mouse brain, heart, liver and kidney. 


\section{Material and Methods}

Animals

Twenty four CBA strain female mice (3-4 month old individuals) of approximate $20 \mathrm{~g}$ weight were involved in the study. The animals were housed under standard laboratory conditions and had free access to water and food. They were kept at a temperature of $22-24^{\circ} \mathrm{C}$ with a light/dark cycle of $12 \mathrm{~h}$.

\section{Study protocol}

The study has been performed in accordance with the guidelines for the care and use of laboratory animals accepted by the Bioethical Committee of the Jagiellonian University Medical College.

The study design comprised intraperitoneal administration of N-acetyl-p-aminophenol of $30 \mathrm{mg} / \mathrm{kg}$ body weight per day $(0.6 \mathrm{mg} / \mathrm{d}$ - group D1, $\mathrm{n}=8)$ or $100 \mathrm{mg} / \mathrm{kg}$ body weight per day $(2.0 \mathrm{mg} / \mathrm{d}$ - group $\mathrm{D} 2, \mathrm{n}=8$ ) for 5 consecutive days at the same time of the day $(10: 30 \mathrm{am})$. N-acetyl-p-aminophenol (Paracetamol, Biofarm, Poland) was dissolved in physiological saline (each injection contained 0.2 $\mathrm{ml}$ of the solution). The control group $(\mathrm{n}=8)$ received intraperitoneally physiological saline in portions of the same volume. The individuals were randomly assigned to each group. The animals tolerated the applied doses of paracetamol well and remained in good condition till the end of the experiment. Measurements of $\mathrm{H}_{2} \mathrm{~S}$ concentration were performed by the use of the modified method of Siegel (SIEGEL 1965; SOMOGYI et al. 2008).

\section{Tissue sample preparation}

The animals were killed by cervical dislocation 2 hours after the last drug or physiological saline injection. Their brains, hearts, livers and kidneys were quickly removed and homogenized with $0.01 \mathrm{~mol} / 1$ sodium hydroxide $(\mathrm{NaOH})$ : brain tissue in proportion of 1 to 3, liver of 1 to 5, heart and kidney of 1 to 10 and frozen. Then $50 \%$ trichloroacetic acid
(TCA) was added $(0.5 \mathrm{ml}$ to $2 \mathrm{~g}$ of brain or liver samples in tight capsules of $3 \mathrm{ml}$ and $0.25 \mathrm{ml}$ to $1 \mathrm{~g}$ of heart or kidney samples in tight capsules of $2 \mathrm{ml}$ ), the suspension was shaken and centrifuged. Subsequently, $1.5 \mathrm{ml}$ of brain or liver and $0.75 \mathrm{ml}$ heart or kidney supernatant samples were moved to $2 \mathrm{ml}$ tight capsules with $0.15 \mathrm{ml}$ or $0.075 \mathrm{ml}$ of 0.02 $\mathrm{mol} / \mathrm{l} \mathrm{N}, \mathrm{N}$-dimethyl-p-phenyl-diamine sulfate in $7.2 \mathrm{~mol} / 1$ hydrochloric acid $(\mathrm{HCl})$, then $0.15 \mathrm{ml}$ or $0.075 \mathrm{ml}$ of $0.03 \mathrm{~mol} / 1$ iron (III) chloride $\left(\mathrm{FeCl}_{3}\right)$ in $1.2 \mathrm{~mol} / 1 \mathrm{HCl}$ portions were added, respectively. After 20 minutes in darkness the content was shaken for 1 minute with $1 \mathrm{ml}$ of chloroform.

\section{$\mathrm{H}_{2} \mathrm{~S}$ tissue concentration measurement}

Absorbance was measured at $650 \mathrm{~nm}$ with the Varian Cary 100 spectrophotometer. A standard curve was prepared with an iodometrically determined $0.0001 \mathrm{~mol} / 1$ sodium sulfide $\left(\mathrm{Na}_{2} \mathrm{~S}\right)$ solution. For each group of animals four concurrent analyses of every analyzed tissue type were performed.

\section{Statistical analysis}

Statistical analysis was performed within the $\mathrm{R}$ Environment by the Student's $t$-test. Statistical significance was considered when $\mathrm{P}<0.05$.

\section{Results and Discussion}

There was a significant rise in the $\mathrm{H}_{2} \mathrm{~S}$ tissue concentration in D1 and D2 groups in the heart and kidney, the increase was more pronounced in the group with the lower paracetamol dose as compared to the group of drug higher dose. Conversely, in the brain the $\mathrm{H}_{2} \mathrm{~S}$ tissue level decreased but more in the lower acetaminophen dose group. In the liver only a higher paracetamol dose evoked $\mathrm{a}_{2} \mathrm{~S}$ concentration change, i.e. its level increased after $100 \mathrm{mg} / \mathrm{kg}$ of acetaminophen administration. The results are presented in Table 1.

Table 1

Hydrogen sulfide $\left(\mathrm{H}_{2} \mathrm{~S}\right)$ tissue concentrations in mouse brain, heart, liver and kidney following administration of $30 \mathrm{mg} / \mathrm{kg} \mathrm{b.w./d}$ or $100 \mathrm{mg} / \mathrm{kg} \mathrm{b.w./d} \mathrm{of} \mathrm{paracetamol} \mathrm{(groups} \mathrm{D1} \mathrm{and} \mathrm{D2}$ respectively)

\begin{tabular}{||l|c|c|c|c|c||}
\hline $\begin{array}{c}\mathrm{H}_{2} \mathrm{~S} \text { tissue concentration } \\
(\mu \mathrm{g} / \mathrm{g})\end{array}$ & $\begin{array}{c}\text { Control group } \\
(\mathrm{n}=8)\end{array}$ & $\begin{array}{c}\mathrm{D} 1 \\
(\mathrm{n}=8)\end{array}$ & $\begin{array}{c}\mathrm{P} \\
(\text { control vs D1) }\end{array}$ & $\begin{array}{c}\mathrm{D} 2 \\
(\mathrm{n}=8)\end{array}$ & $\begin{array}{c}\mathrm{P} \\
\text { (control vs D2) }\end{array}$ \\
\hline Brain & $1.47 \pm 0.02$ & $0.80 \pm 0.02$ & $<0.01$ & $1.05 \pm 0.02$ & $<0.01$ \\
\hline Heart & $6.89 \pm 0.14$ & $8.12 \pm 0.16$ & $<0.01$ & $7.35 \pm 0.10$ & $<0.01$ \\
\hline Liver & $3.92 \pm 0.06$ & $3.95 \pm 0.07$ & 0.54 & $4.65 \pm 0.09$ & $<0.01$ \\
\hline Kidney & $7.13 \pm 0.07$ & $9.60 \pm 0.14$ & $<0.01$ & $8.36 \pm 0.14$ & $<0.01$ \\
\hline
\end{tabular}


A debate about paracetamol's primary site of action has been ongoing in the literature for years. Much investigation has focused on acetaminophen's inhibition of prostaglandin (PG) synthesis, because its analgesic and antipyretic properties resemble the effects of aspirin and other nonsteroidal anti-inflammatory drugs (NSAIDs). Synthesis of prostaglandin $\mathrm{H}_{2}\left(\mathrm{PGH}_{2}\right)$ is a crucial stage in arachidonic acid metabolism and is catalyzed by two major forms of $\mathrm{PGH}_{2}$ synthetase (PGHS) - constitutive PGHS-1 and inducible PGHS-2. PGHS contains two sites: a cyclooxygenase (COX) site and a peroxidase (POX) site. Paracetamol acts as a reducing cosubstrate on the POX site and lessens the availability of the ferryl protoporphyrin IX radical cation, essential for conversion of tyrosine-385 to its radical form, which is necessary for the transformation of arachidonic acid to prostaglandin $\mathrm{G}_{2}\left(\mathrm{PGG}_{2}\right)$ on the COX site. What is noteworthy, this effect can be reduced in the presence of hydroperoxidegenerating lipoxygenase enzymes within the cell (peroxide tone) or by swamping the POX site with substrate such as $\mathrm{PGG}_{2}$ (ANDERSON 2008). Some hope was also associated with the discovery of a variant of PGHS-1 (named PGHS-1b or COX-3), sensitive to inhibition with paracetamol and active in the cerebral cortex of canines, but subsequent research found it improbable to play a role in PGmediated fever and pain in humans and mice (CHANDRASEKHARAN et al. 2002; KIS et al. 2005).

As paracetamol seems to not have major effects peripherically, its action appears to be mostly central. Peroxide tone and swamping might explain the lack of peripheral analgesic, platelet and anti-inflammatory effects by acetaminophen but alternative PGHS inhibition mechanisms have been also proposed (BERTOLINI et al. 2006). Inhibition of the L-arginine - nitric oxide (NO) pathway mediated through substance P or N-methyl-D-aspartatic acid (NMDA), reinforcement of descending inhibitory serotonergic pain pathways and active paracetamol metabolites ( $\mathrm{p}$-aminophenol conjugated with arachinodic acid by fatty acid amide hydrolase forming AM404) exerting effect through cannabinoid receptors are postulated (ANDERSON 2008; BJORKMAN et al. 1994; BUJALSKA 2004; HOGESTATT et al. 2005; OTTANI et al. 2006; PICKERING et al. 2008).

Hydrogen sulfide is endogenously formed from L-cysteine in several enzymatic reactions, catalyzed by cystathionine $\beta$-synthase (CBS), cystathionine $\gamma$-lyase (CSE)) and 3-mercaptopyruvate sulfurtransferase (3MST), and in non-enzymatic pathways in many tissues, especially in the nervous, cardiovascular, digestive and excretory systems. $\mathrm{H}_{2} \mathrm{~S}$ participates in the regulation of various physiological and pathophysiological processes including neurotransmission, immune and inflam- matory processes, and perception (FIORUCCI et al. 2006; ŁOWICKA \& BEŁTOWSKI 2007). $\mathrm{H}_{2} \mathrm{~S}$ is involved in multiple nociception signaling pathways with increasing cAMP levels in neuronal and glial cell lines, activation of T-type calcium channel and ATP-sensitive potassium channels $\left(\mathrm{K}_{\mathrm{ATP}}\right)$, sensitization of the NMDA receptor complex and activation of TRPA1 (transient receptor potential cation channel, subfamily A, member 1) ion channels (CUNHA et al. 2008; DISTRUTTI et al. 2006; MATSUNAMI et al. 2009; SMITH 2009; STRENG et al. 2008; TODOROVIC \& JEVTOVIC-TODOROVIC 2006). Moreover, $\mathrm{H}_{2} \mathrm{~S}$ interacts with $\mathrm{NO}$ and carbon monoxide (CO) in a complex manner including affecting each other's synthesis and biological responses within target tissues and organs depending on specific environmental circumstances (LI et al. 2009). $\mathrm{H}_{2} \mathrm{~S}$ has been shown to display various effects which promote neutrophil migration, upregulation of COX-2 and production of inflammatory mediators with prostaglandin $\mathrm{E}_{2}\left(\mathrm{PGE}_{2}\right)$ which appears to act on nociceptor membranes (CUNHA et al. 1992; Hu et al. 2008; SMITH 2009). On the other hand, it is has been suggested that $\mathrm{H}_{2} \mathrm{~S}$ could be produced in the inflammatory site by $\mathrm{mi}-$ grating leukocytes (CUNHA et al. 2008).

As we have demonstrated, paracetamol elicits changes in $\mathrm{H}_{2} \mathrm{~S}$ tissue concentrations reflecting alterations in the transmitter generation. Since $\mathrm{H}_{2} \mathrm{~S}$ has been recognized to be involved in a wide variety of processes of nociception with its predominant role of activation of T-type calcium channels leading to facilitation of pronociceptive actions, the observation that acetaminophen decreases the $\mathrm{H}_{2} \mathrm{~S}$ level is quite an enticing finding (ANDERSON 2008). The role of $\mathrm{H}_{2} \mathrm{~S}$ mediation of paracetamol's central analgetic effects is definitely a field for future research, especially when considering common features in the biological action of acetaminophen and $\mathrm{H}_{2} \mathrm{~S}$ such as involvement of the NMDA receptor, transient receptor potential vanilloid (TRPV) ion channels system and NO. Secondly, $\mathrm{H}_{2} \mathrm{~S}$ tissue concentration changes in heart, liver and kidneys indicate that paracetamol exerts peripheral effects in different organs with possible involvement of PGHS. Interaction between prostaglandins and $\mathrm{H}_{2} \mathrm{~S}$ seems to be complex, including each other's generation and effects. Moreover, it appears that effects of $\mathrm{H}_{2} \mathrm{~S}$ vary depending on the environment and circumstances under which it co-acts with other messengers in the specific setting of different organs.

Paracetamol is another drug shown to affect $\mathrm{H}_{2} \mathrm{~S}$ production next to NSAIDs and angiotensinconverting enzyme inhibitor (ACEI) ramipril, encouraging further research of the messenger role in physiology and pathology of different systems 
(FIORUCCI et al. 2007; SREBRO et al. 2006; WILIŃSKI et al. 2010; WILIŃSKI et al. 2008).

\section{References}

ANDERSON B. J. 2008. Paracetamol (Acetaminophen): mechanisms of action. Paediatr. Anaesth. 18: 915-921.

Bertolini A., Ferrari A., OtTani A., Guerzoni S., TACCHI R., LEONE S. 2006. Paracetamol: new vistas of an old drug. CNS Drug Rev. 12: 250-275.

Bjorkman R., Hallman K. M., Hedner J., Hedner T., HENNING M. 1994. Acetaminophen blocks spinal hyperalgesia induced by NMDA and substance P. Pain 57: 259-264.

BUJALSKA M. 2004. Effect of nitric oxide synthase inhibition on antinociceptive action of different doses of acetaminophen. Pol. J. Pharmacol. 56: 605-610.

ChandRasekharan N. V., Dai H., RoOs K. L., Evanson N. K., TOMSIK J., ElTON T. S., SimMONS D. L. 2002 COX-3, a cyclooxygenase-1 variant inhibited by acetaminophen and other analgesic/antipyretic drugs: cloning, structure, and expression. Proc. Natl. Acad. Sci. USA 99: 13926-13931.

Cunha F. Q., Poole S., LorenzetTI B. B., Ferreira S. H 1992. The pivotal role of tumour necrosis factor alpha in the development of inflammatory hyperalgesia. Br. J. Pharmacol. 107: 660-664.

Cunha T. M., DAl-SEcco D., VerRi W. A. Jr., Guerrero A. T., SouZA G. R., Vieira S. M., Lotufo C. M., NeTO A. F., FERREIRA S. H., CUNHA F. Q. 2008. Dual role of hydrogen sulfide in mechanical inflammatory hypernociception. Eur. J. Pharmacol. 590: 127-135.

Distrutti E., Sediari L., Mencarelli A., Renga B., ORLANDI S., RUSSO G., CALIENDO G., SANTAGADA V., CiRino G., WALLACE J. L., FioRUCCI S. 2006. 5-Amino-2hydroxybenzoic acid 4-(5-thioxo-5H-[1,2]dithiol3yl)-phenyl ester (ATB-429), a hydrogen sulfide-releasing derivative of mesalamine, exerts antinociceptive effects in a model of postinflammatory hypersensitivity. J. Pharmacol. Exp. Ther. 319: 447-458.

FioruCCi S., DistrutTi E., Cirino G., WALlaCE J. L. 2006. The emerging roles of hydrogen sulfide in the gastrointestinal tract and liver. Gastroenterology 131: 259-271.

FIORUCCI S., SANTUCCI L., DistrutTI E. 2007. NSAIDs, coxibs, CINOD and H2S-releasing NSAIDs: what lies beyond the horizon. Dig. Liver Dis. 39: 1043-1051.

Hogestatt E. D., Jonsson B. A., ERMUnd A., ANDERSSON D. A., B.ork H., AleXander J. P., CRAvatT B. F., BASBAUM A. I., ZYGMUNT P. M. 2005. Conversion of acetaminophen to the bioactive $\mathrm{N}$-acylphenolamine AM404 via fatty acid amide hydrolase-dependent arachidonic acid conjugation in the nervous system. J. Biol. Chem. 280: 31405-31412.

Hu L. F., Pan T. T., Neo K. L., Yong Q. C., Bian J. S. 2008. Cyclooxygenase- 2 mediates the delayed cardioprotection induced by hydrogen sulfide preconditioning in isolated rat cardiomyocytes. Pflugers Arch. 455: 971-978.

Kis B., SNiPES J. A., BusiJA D. W. 2005. Acetaminophen and the cyclooxygenase-3 puzzle: sorting out facts, fictions, and uncertainties. J. Pharmacol. Exp. Ther. 315: 1-7.

Lee A. T., Shah J. J., Li L., Cheng Y., Moore P. K., KHANNA S. 2008. A nociceptive-intensity-dependent role for hydrogen sulphide in the formalin model of persistent inflammatory pain. Neuroscience 152: 89-96.

Li L., Hsu A., MoORE P. K. 2009. Actions and interactions of nitric oxide, carbon monoxide and hydrogen sulphide in the cardiovascular system and in inflammation - a tale of three gases! Pharmacol. Ther. 123: 386-400.

Matsunami M., TARUI T., Mitani K., Nagasawa K., FUKUSHIMA O., OKUBO K., YOSHIDA S., TAKEMURA M., KAWABATA A. 2009. Luminal hydrogen sulfide plays a pronociceptive role in mouse colon. Gut 58: 751-761.

OTTANI A., LEONE S., SANDRINI M., FERRARI A., BERTOLINI A. 2006. The analgesic activity of paracetamol is prevented by the blockade of cannabinoid CB1 receptors. Eur. J. Pharmacol. 531: 280-281.

ŁOWICKA E., BEŁ TOW SKI J. 2007. Hydrogen sulfide (H2S) the third gas of interest for pharmacologists. Pharmacol. Rep. 59: 4-24.

Pickering G., Esteve V., LoRiot M. A., Eschalier A., DUBRAY C. 2008. Acetaminophen reinforces descending inhibitory pain pathways. Clin. Pharmacol. Ther. 84: 47-51.

SiEGEL L. M. 1965. A Direct Microdetermination for Sulfide. Anal Biochem 11: 126-32.

SMITH H. S. 2009. Hydrogen sulfide's involvement in modulating nociception. Pain Physician 12: 901-910.

Somogyi E., PiotrowsKa J., RZESZUTKO W. 2008. An effect of some parameters of the determination of the hydrogen sulfide in pig liver and brain on the obtained results. Farm. Prz. Nauk. 5: 33-36. (In Polish with English summary).

SREBro Z., SOMOGYI E., WilińsKi B., GÓRALSKA M., WILIŃSKI J., SURA P. 2006. Aspirin augments the concentration of endogenous hydrogen sulfide in mouse brain and liver. Folia Med. Cracov. 47: 87-91.

Streng T., AXElsson H. E., Hedlund P., ANDERsSON D. A. JORDT S. E., BEVAN S., ANDERSSON K. E. HOGESTATT E. D., ZYGMUNT P. M. 2008. Distribution and function of the hydrogen sulfide-sensitive TRPA1 ion channel in rat urinary bladder. Eur. Urol. 53: 391-399.

TODOROVIC S. M., JEVTOVIC-TODOROVIC V. 2006. The role of T-type calcium channels in peripheral and central pain processing. CNS Neurol Disord Drug Targets 5: 639-653.

WiLiński B., Wiliński J., SOMOgYI E., GÓRAlska M., PIOTROWSKA J. 2010. Ramipril affects hydrogen sulfide generation in mouse liver and kidney. Folia Biol. (Kraków) 58: $57-61$.

WiLIŃSKi J., SOMOGYI E., GÓRALSKA M., WiLiŃSKi B., CZARNECKA D. 2008. Ramipril enhances the endogenous hydrogen sulfide tissue concentration in mouse heart and brain. Folia Med. Cracov. 49: 123-130. 